\title{
MAXIMIZING SOCIAL VALUE IN THE HOTEL ONLINE ENVIRONMENT USING AN ANALYTIC HIERARCHY PROCESS
}

\section{- Carmen Păunescu, Remus Moraru}

\begin{abstract}
The paper analyses the possibilities that hoteliers have to create and maximize the social value of their online platforms, in terms of their functionality and usage, in order to improve sales and increase hotels' performance. It also discusses the opportunities that hotel managers can take to improve the hotel online decision-making strategy to convert more effectively visitors into actual customers. Although social value creation of online platforms has been well researched in the specialized literature, recent research has not examined the ways the online social value can be maximized and put into effective commercial use. The paper reviews the dimensions and characteristics of the hotel online environment by integrating literature analysis and field research practices. It employs the analytic hierarchy process method to analyse key elements of the hotel online environment that can serve as a focal point for value creation. The literature review and field research conducted pinpoint three possibilities of creating online social value: (a) building online trust, (b) ensuring high quality of the online service, and (c) providing effective online communication experience. The paper results have given deeper understanding regarding potential areas of the hotel online environment where social value can be obtained. They prove applicability of the analytic hierarchy process method for evaluation and selection of strategies for online social value creation. At the same time, the paper provides new valuable insights to hoteliers, which might support their decisions to improve the business by proactively incorporating strategies for online social value maximization.
\end{abstract}

Keywords: social value, hotel online environment, value creation, analytic hierarchy process, hotel business strategy, decision-making

JEL Classification: M19, O35, Z32

\section{INTRODUCTION}

The evolution of online technologies and growing popularity of online services across different markets and businesses had prompted companies to reconsider their strategies for development and growth, and invest more in innovation. This allows them to expand their services and increase usability of their online platforms to better serve the shifting needs of their customers. The broad introduction of internet technology to business in general has led to its wide-scale application in the tourism and hotel industry (Law \& Jogaratman, 2005). Customers have been increasingly using the internet to search for accommodation-related information and other services on hotel websites (Law \& Hsul, 2006; lliott \& Meng, 2011), online social networks (Freedman \& Jin, 2017) and online reviews (Sparks \& Browning, 2011). Also, with the increasing 
penetration of the internet into households, hotels realized the importance and benefits of the online environment and have started to put it into commercial use.

Although since the early 2000s, the online hotel industry has shown an incredible pace of growth (Elliott \& Meng, 2011), the continuous evolution of the technology and the growth of the online markets challenged hoteliers to explore new boundaries and strategies that will convert online visitors into actual guests. Even so, the vast majority of hotels do not understand their online environment well. Only a very small percentage are aware of the opportunities they have to improve sales (occupancy) and profits by using online tools and emphasizing the social value of hotel online platforms, either in terms of actual layout, functionality or usage. Nowadays, hotels should demonstrate capability to understand the potential and the usages of their online environment and prepare a business online strategy accordingly, which can build up demand, create value and, in the same time, generate social value directly and/or indirectly. Identification and mapping of this environment is crucial in order for the hotels to understand the connection between processes, guest interaction and the final output that is social value.

Social value creation of online platforms has been well researched in the tourism and hospitality literature (Prahalad \& Ramaswamy, 2004; Daun \& Klinger, 2006; Chiang \& Shawn Jan, 2007; Wu \& Liang, 2009; Xie et al., 2014; Ye et al., 2014; Goh et al., 2016). Developing online environment and value creation have become the dominant themes for hotel managers. Although some scholars advocate creating online quality service and value encounters to enhance customer satisfaction, recent research has not examined the ways social value of hotel online platforms can be maximized and put more effectively into commercial use.

The current paper attempts to analyse the possibilities the hoteliers have to enhance the social value of their hotel online environments in order to remain competitive in the industry and continuously increase sales. It aims to answer two main questions. Firstly, how the hoteliers can create and maximize the social value of their online platforms in order to increase hotels' revenue. Also, what potential areas of the hotel online environment generate social value, which is easily noticed by visitors. Secondly, how the hoteliers can improve the hotel online decisionmaking strategy. Therefore, the first part of the paper discusses the dimensions of the online environment of the hotel, based on literature review and field research, to understand through which online channels hotels can have the possibility to create social value. Also, we looked at potential sources of value creation in the hotel online environment. Then, we used the analytic hierarchy process super decision software to understand the traveller-hotelier communication and the hotel online decision-making strategy. The analytic hierarchy process analysis will provide a practical approach to evaluation and selection of the most appropriate business strategy to be adopted by hotels that seek to maximize their online social value.

\section{THEORETICAL ASPECTS OF SOCIAL VALUE IN THE HOTEL ONLINE ENVIRONMENT}

The online environment of the hotel is a multitude of self or partially self-managed online channels that serve as a point of contact between online users and the hotel. These channels by nature can serve various purposes such as sales, marketing, customer service, or product/serv- 
ice innovation. There are various online channels a hotel can use to target potential customers (Carroll \& Siguaw, 2003; Sparks \& Browning, 2011; Hsieh, 2012). Channels such as online travel agencies, review websites or the hotel own websites allow a two-way communication between the hotel and the users. This communication helps to share vital information both for the travellers and the hoteliers and allows hotels to create value through information that directly or indirectly generates social value. For example, Law (2009) shows that experienced online buyers were more positive towards technologyassisted hotel bookings and less positive towards travel agents relative to their less experienced peers. Since the appearance of the web 2.0 era, technology usability and interoperability have been reshaping modern day website and business models (Tanău \& Khorshidi, 2016). Same applies to the hotel industry where hotel websites need to capitalize on the growing demand that comes through various online channels (Law et al., 2004; Pranić et al., 2014).

To evaluate if the hotel has a well-established online environment, the field literature, preliminary cases and industry standards (e.g., Law \& Hsul, 2006; Schmidt et al., 2008; Akehust, 2009; Rong et al., 2009; Elliott \& Meng, 2011; Hsieh, 2012; Ip et al., 2012; Browning et al., 2013) refer to a perimeter consisting of four key dimensions: a) the hotel own website including a mobile website or mobile application; b) social media platforms; c) online distribution channels; and d) review websites. These four channels play an important role in the hotel online strategy and together they maximize the online potential, meaning that hotels can build a successful online strategy and environment for themselves and for their visitors or customers.

In the academic literature, the website quality has widely been recognized as a critical step to drive the business online (e.g., Rong et al., 2009). Bai et al. (2008) show that the website quality has a direct and positive impact on the level of customer satisfaction, and that the customer satisfaction level influences directly and positively the purchase intentions. According to Schmidt et al. (2008), most private hotel websites have only a limited range of functions that do not bring much benefit to visitors and potential travellers. A website should be every hotel digital lobby and reception that allows potential guest to connect, get informed about the hotel and interact with the platform in undertaking actions such as booking a room or a service. The following features that underline the key elements of a hotel website are vital: room and facility information, surrounding area information, communication, social proof, and booking engine (Law \& Hsul, 2006; Schmidt et al., 2008; Elliott \& Meng, 2011). Social proof, for example, such as testimonials, guest reviews and social media links, is a crucial key element of the hotel website that needs close attention. Since the appearance of social media websites and review websites such as TripAdvisor (www.tripadvisor.com), customers increasingly share experience directly with other customers through electronic word of mouth (Akehurst, 2009). As such, hotels have to make the search easy for customers by creating links between social media sites and hotel own website, so users can easily navigate through the hotel generated content both on social media platforms and on its own website. The booking engine is another key feature of the hotel website that needs more care as without a well-engineered and well-structured booking engine, the website will not convert visitors into customers that actually book a room and visit the hotel.

Social media platforms become unquestionably an important way to communicate and engage customers. Hotels can apply for a handful of social media strategies depending on the customers 
they want to engage. The use of social media platforms in the hotel industry is starting to become a standard. However, hotels have to clearly define which social media platform they shall use as not all platforms target the desired audience and location (Leung et al., 2015). The activity on social media platforms is crucial, having an active community talking about the hotels brand, activities, and offer. It helps the hotel establish a loyal customer base that attracts possible new customers along the way. However, a recent research argues that online value creation is not necessarily dependent upon the underlying social interactions but predominantly influenced by personal factors and attitudes towards sociability (Reichenberger, 2017).

The online environment has opened new ways to communicate and to buy and sell products and services. As such, the online channels are one of the most efficient channels to increase a hotel's revenue, with far less energy and investment as traditional offline sales. With the increasing popularity of internet applications and penetration of internet in households, hotel managers and travel agents should set practical plans to meet the needs of online buyers (Law, 2009). A hotel may have several online channels that serve as a way to get more bookings like: online travel agencies, hotel search engines, metasearch websites, wholesalers, and other channels (see for example Chiang \& Shawn Jang, 2007; Law, 2009).

Over the past decade, review websites gained more and more interest in the hospitality industry. Through these websites, customers of hotels can share their experience and thoughts about a hotel overall services or a particular service. These mediums are also a vital point of contact for hotels to communicate and to elevate possible complaints. McIntyre at al. (2016) argue that the online review will influence success or failure of reviewed businesses. In their study, Browning et al. (2013) state that review websites can provide hotels with a very rich and informative source of customer feedback that will allow them to pinpoint the key areas needing improvement and more care. Also, Ye et al. (2011) show that traveller reviews have a significant impact on online bookings and sales, highlighting the importance of online user-generated reviews to hotel business performance.

The above mentioned key elements of the hotel online environment could serve as a focal point for social value creation. The existing literature in the tourism and hospitality industry and also other similar business services (e.g., Prahalad \& Ramaswamy, 2004; Daun \& Klinger, 2006; Chiang \& Shawn Jang, 2007; Sparks \& Browning 2011; Padilla-Melendez \& Rosa del Aguila-Obra, 2013; Xie et al., 2014; Ye et al., 2014; Alshibly, 2015; Hu et al., 2015; Goh et al., 2016), relate broadly to three possibilities of creating social value in the online environment: (a) building online trust, described as reduced risk and uncertainty of using online channels and by availability of relevant and reliable information; (b) ensuring high quality of the online service, in terms of the size and volume of information shared, access speed, usability, comparisons, way of interaction (for booking a room, booking a service, etc.); and (c) providing effective online communication experience, which includes a two-way communication and different forms of customer engagement like a personalized online channel, online suggestion box, immediate feedback, etc. Tab. 1 briefly presents the main sources of social value creation in the hotel online environment and their defining components. 
Tab. 1 - Sources of social value creation in the hotel online environment. Source: Authors' own research. Processed and based on literature review and field research

\begin{tabular}{|c|c|c|}
\hline Online trust & Online service quality & Online communication experience \\
\hline $\begin{array}{l}\text { Hotel feedback } \\
\text { Hotel ranking } \\
\text { Quality of listing } \\
\text { Reviews intensity } \\
\text { and trends } \\
\text { Live rates and avail- } \\
\text { ability of informa- } \\
\text { tion } \\
\text { Secure booking page }\end{array}$ & $\begin{array}{l}\text { Room information } \\
\text { Facilities information } \\
\text { Location map } \\
\text { Pictures/videos } \\
\text { Links to social media } \\
\text { Organic ranking on search } \\
\text { engines } \\
\text { Availability on Google Maps } \\
\text { Loading speed } \\
\text { Mobile friendly website } \\
\text { Mobile enabled site options } \\
\text { Payment gateway }\end{array}$ & $\begin{array}{l}\text { Online travel agencies } \\
\text { Hotel search engines } \\
\text { Metasearch websites } \\
\text { Wholesalers } \\
\text { Other channels (local, regional, } \\
\text { global) } \\
\text { Active TripAdvisor page } \\
\text { Active Facebook page for business } \\
\text { Active Twitter page } \\
\text { Active other social media page }\end{array}$ \\
\hline
\end{tabular}

Studies show that trust appears to play an important role in improving long-term customer added value in online environments (e.g., Chiang \& Shawn Jang, 2007). According to Shankar et al. (2002), online trust can be examined from the perspective of different stakeholders such as customers, employees, suppliers, distributors, partners, stockholders, and regulators. In case of the hotel online environment, we delimit two major perspectives: the perspective of the customer as B2C and that of partners and distributors as B2B. Corritore et al. (2005) discuss two levels of analysis when it comes to the online trust, such as external factors that influence the online trust and the individual trustor's perception of these factors. Such factors refer, for example, to credibility, ease of use, and risk, all of them having a major impact on a user's degree of trust in a website and on the decision making process for those individuals who visit the hotel online environment. Furthermore, Alshibly (2015) notes in his recent research on customer perceived value in social commerce that the online trust and online service quality have a direct influence on online social value.

In their study on perception of trust, Sparks \& Browning (2011) found that consumers seem to be more influenced by early negative feedback and tend to rely on easy-to-process information, when evaluating a hotel based upon reviews and feedback. However, positively framed information associated with good numerical rating details increases both booking intentions and consumer trust. A study conducted by Jarvenpaa \& Leidner (1998, p. 7) on communication and trust in virtual teams showed that "inequitable, irregular, and unpredictable communication hindered trust". This suggests that communication could be the fourth important factor that completes Corritore et al.'s (2005) list of trust factors previously mentioned. 
Another study on the use of online travel reviews as a persuasive communication tool and their effect on consumer behaviour shows that "customer-generated content generally is viewed more trustworthy than manager-generated content" (Sparks et al., 2013, p. 22). As such, it is extremely important to highlight others' opinion about the hotel to increase trustworthiness and conversion. In what regards the quality of hotel online service, Shankar et al. (2003) argue that whereas the levels of customer satisfaction for quality of a service chosen online is the same as when it is chosen offline, probability to build loyalty to the service provider is higher and further strengthened when the service is offered online rather than offline. A satisfied customer positively reinforces loyalty and influences the quality of the service chosen online.

\section{OBJECTIVES AND METHODOLOGY}

The paper employs an analytic hierarchy process model to determine the most suitable business strategy to be adopted by hotels that seek to maximize their online social value. The Analytic Hierarchy Process (AHP) is a methodology for structuring, measuring, organizing and analysing complex decisions, based on mathematics and psychology (Saaty, 2008). Due to its wide applicability and ease of use, the analytic hierarchy process has been researched extensively for the last 20 years, as such the academic literature in the field becomes quite rich and comprehensive (e.g., Ordoobadi, 2010; Ho et al., 2011; Saaty \& Vargas, 2012; Aykan \& Dagdeviren 2014; Hasan \& Rahman, 2017, to name a few more recent studies in the area). The main philosophy behind the AHP lies in the fact that it structures the decision problem (or goal) by decomposing it into a hierarchy of elements (namely criteria, sub-criteria and alternatives) independently analysable (Saaty 1987). These could be both tangible and intangible aspects of the problem, subjective and objective evaluation factors, which minimize preference in the decision making process.

The research model developed in the paper builds upon the AHP methodology and uses SuperDecisions $\mathbb{C}$ software. Our settled goal is that of determining the most suitable business strategy to be adopted by hotels that seek to create and maximize their online social value (see Fig. 1). Based on the literature review and field research, we formulated the following alternative strategies for creating online social value for hotels, from among which the experts from the online hotel environment were asked to choose: A1 - Developing online trust characterized by a reduced risk and uncertainty of using the online channels and by the availability of relevant and reliable information; A2 - Providing a high quality online service measured relative to the size and volume of information shared, speed of access, usability, comparisons, way of interaction; and A3 - Ensuring online effective communication experience described as a two-way communication, multiple forms of customer engagement, such as a personalized online channel, online suggestion box, immediate feedback, etc. The following criteria, found in the literature, were taken into account in order to make the final decision: C1 - Hotel website, C2 - Social media platforms, C3 - Online distribution channels, and C4 - Review websites. 


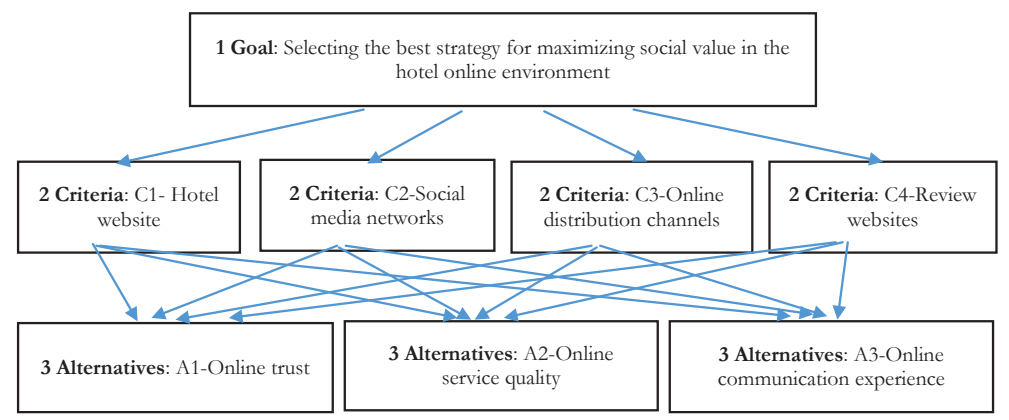

Fig. 1 - Hierarchy for choosing the most suitable strategy for maximizing social value in the hotel online environment. Source: Authors' own research

Fig. 1 depicts the network connections between the goal and the criteria and between certain criteria and certain alternatives to describe relationship between them. The analysis is meant to determine which of the three alternative strategies is the most suitable regarding to the importance the evaluators place on specific criteria. The method utilizes a numerical scale made of absolute numbers that was demonstrated practically and approved by physical and decision issue tests (Liang et al., 2008; Saaty \& Vargas, 2012). This fundamental scale extends from 1 - equal importance (two activities contribute equally to the goal) to 9 - extreme importance (one activity is favoured over another at the highest possible order of affirmation). The scale shows personal preferences regarding both criteria and alternatives, and helps with turning individual preferences into weights. The resultant weights are further utilized to rank the choices made and settle on a final decision. Thus, AHP simplifies preference ratings among decision criteria using pairwise comparisons. The pair-wise comparison matrix of the criteria $(\mathrm{C} 1, \mathrm{C} 2, \ldots, \mathrm{Cn})$ according to their importance (i1, i2, .., in) is shown in Fig. 2. The pair-wise comparison means that the criteria in the row is being compared to the criteria in the column.

\begin{tabular}{|l|l|l|l|l|l|}
\hline & $\mathrm{C}_{1}$ & $\mathrm{C}_{2}$ & $\mathrm{C}_{3}$ & $\ldots$ & $\mathrm{C}_{\mathrm{n}}$ \\
\hline $\mathrm{C}_{1}$ & 1 & $\mathrm{i}_{1} / \mathrm{i}_{2}$ & $\mathrm{i}_{1} / \mathrm{i}_{3}$ & $\ldots$ & $\mathrm{i}_{1} / \mathrm{i}_{\mathrm{n}}$ \\
\hline $\mathrm{C}_{2}$ & $\mathrm{i}_{2} / \mathrm{i}_{1}$ & 1 & $\mathrm{i}_{2} / \mathrm{i}_{3}$ & $\ldots$ & $\mathrm{i}_{2} / \mathrm{i}_{\mathrm{n}}$ \\
\hline $\mathrm{C}_{3}$ & $\mathrm{i}_{3} / \mathrm{i}_{1}$ & $\mathrm{i}_{3} / \mathrm{i}_{2}$ & 1 & $\ldots$ & $\mathrm{i}_{3} / \mathrm{i}_{\mathrm{n}}$ \\
\hline$\cdot$ &. &. &. & $\ldots$ &. \\
\hline $\mathrm{C}_{\mathrm{n}}$ & $\mathrm{i}_{\mathrm{n}} / \mathrm{i}_{1}$ & $\mathrm{i}_{\mathrm{n}} / \mathrm{i}_{2}$ & $\mathrm{i}_{\mathrm{n}} / \mathrm{i}_{3}$ & $\ldots$ & 1 \\
\hline
\end{tabular}

Fig. 2 - Pairwise comparison matrix of the criteria

Having the comparison matrix, we can compute the priority vectors which are the normalized Eigen vector of the matrix. Thus, the next step is to normalize the matrix. This is done by totalling the numbers in each column.

$\mathrm{Cij}=\sum_{i=1}^{n} \mathrm{Cij}$ 
Each entry in the column is then divided by the column sum to yield its normalized score. The sum of each column is 1 .

$$
\mathrm{Xij}=\frac{C i j}{\sum_{i=1}^{n} C i j}\left[\begin{array}{ccc}
X 11 & \cdots & X 1 j \\
\vdots & \ddots & \vdots \\
X i 1 & \cdots & X i j
\end{array}\right]
$$

Then, we divide the sum of the normalized column of the matrix by the number of criteria used (n) to generate the weighted matrix. The resultant weights or priority vectors are further used to get corresponding ratings and settle on a final decision.

$\mathrm{Wij}=\frac{\sum_{j=1}^{n} X i j}{n}\left[\begin{array}{c}W 11 \\ W 12 \\ \ldots \\ W 1 j\end{array}\right]$

The research tool used for data collection was a questionnaire built on the hierarchy that emerged from the defining characteristics of the hotel online environment. It comprises pairwise comparisons between criteria with regard to the decision problem (goal) and between alternatives with regard to the corresponding criteria. The questionnaire-based survey was hosted by Google Docs and distributed via e-mails. The questionnaire has three parts which comprise: 1) Six pairwise comparison questions: in the first part of the question the expert was asked to manifest his/her preference with respect to the criteria, meaning to choose one over another, while the second part of the question was meant to ask the respondent to rate on a scale from 1 to 9 the degree to which (s)he prefers the chosen answer, meant to render us the priority vectors of the criteria; 2 ) 12 pairwise comparison questions meant to deliver the priority vectors for the three alternative strategies according to the specified criteria, and 3) Demographic information such as: job title, seniority, field of activity and company name. The questionnaire was distributed via the internet to 30 selected professionals from Romania and Hungary who operate in the hotel online environment (e.g., hotel managers, business developers, online hotel software developers, online marketing consultants, and tour operators), out of which 17 questionnaires have been fully filled in. Due to the complexity of the research and for the purpose of this paper, five completed questionnaires were selected to cover a wide range of roles fulfilled by the key actors operating in the hotel online industry, namely: Respondent 1 - the manager of a small-sized Romanian travel agency, with more than 20 years seniority in the job; Respondent 2 - the founder and CEO of an Hungarian online hotel software company, with three years seniority in the job; Respondent 3 - the business development manager of a metasearch engine for accommodation, with six years seniority; Respondent 4 - the online marketing manager of a metasearch engine for online travel, with five years seniority; and Respondent 5 - a team leader of a five-star hospitality company located in Hungary, with six years seniority in the job. The size of the organizations from which the respondents were selected ranges from small to medium-sized companies. Other studies also looked at a small number of organizational experts to prioritize the factors that influence customer online participation in value co-creation in the service sector (Ip et al., 2012; Hasan \& Rahman, 2017). Data was collected using an online tool in October - November 2016. The responses were successfully double checked and confirmed through face-to-face interviews or phone call conversations in February 2017. The representativeness rendered by the model is given by the role that the key actor from whom we collected responses plays in the hotel online environment, it is not a statistical representativeness (Hadad, 2015). 


\section{RESULTS AND DISCUSSION}

The data gathered through the questionnaire-based survey were processed and analysed with SuperDecisions $\mathbb{C}$, a software developed by Saaty (2008), which offers the final results as synthetized priorities for each alternative strategy and each respondent. These priorities basically reflect the preferred choices for each respondent by placing the alternatives into rankings. The pairwise comparison decision matrix for our four criteria is shown in Tab. 2. The ranking in importance attributed by Respondent 1 to the criteria, according to the values of the obtained priority vectors, is: review websites $(0.43)$, followed by online distribution channels $(0.42)$, hotel website (0.09), and social media networks (0.04). An important resource extracted from the super decision software is the inconsistency index that validates or disproves the value of the judgements made by each respondent for each criterion (Agapie, 2014). In order for a result to be trustworthy, the inconsistency index must not exceed 0.1 , whereas a ratio of 0 is considered to be a perfectly consistent result. In our case, the inconsistency coefficient is 0.10533 , which is normal. According to Respondent 1, the criterion that has the largest influence on the strategy choice is review websites (0.43).

Tab. 2 - Pairwise comparison decision matrix for the criteria and resulting priority vectors.

Source: Authors' own research

\begin{tabular}{|l|c|c|c|c|c|}
\hline $\begin{array}{l}\text { Online social value } \\
\text { strategy }\end{array}$ & $\begin{array}{c}\text { Review } \\
\text { Websites }\end{array}$ & $\begin{array}{c}\text { Hotel } \\
\text { Website }\end{array}$ & $\begin{array}{c}\text { Online } \\
\text { Distribution } \\
\text { Channels }\end{array}$ & $\begin{array}{c}\text { Social Media } \\
\text { Networks }\end{array}$ & $\begin{array}{c}\text { Priority } \\
\text { vectors }\end{array}$ \\
\hline Review Websites & 1 & 7 & 1 & 7 & 0.43404 \\
\hline Hotel Website & $1 / 7$ & 1 & $1 / 7$ & 4 & 0.09539 \\
\hline $\begin{array}{l}\text { Online Distribution } \\
\text { Channels }\end{array}$ & 1 & 7 & 1 & 6 & 0.42291 \\
\hline $\begin{array}{l}\text { Social Media Net- } \\
\text { works }\end{array}$ & $1 / 7$ & $1 / 4$ & $1 / 6$ & 1 & 0.04765 \\
\hline Sum of priority vectors & & & & 1 \\
\hline Inconsistency
\end{tabular}

The pairwise comparison of each criterion (hotel website, social media networks, online distribution channels, and review websites), and, further, the pairwise comparison of the three alternatives (online trust, online service quality, and online communication experience) with respect to each of the criterion led us to the interesting results. Thus, following the responses given by the other selected experts, the ranking in importance attributed by them to criteria that influence the strategy selection gives priority to criteria like hotel websites and online distribution channels (Appendix 1). The pairwise comparison decision matrix of the alternatives for hotel website as it results from the answers given by Respondent 1 is shown in Tab 3. The ranking in importance attributed by respondent to the alternatives with respect to the hotel website is (Tab. $3)$ : providing online service quality (0.64), ensuring online effective communication experience (0.27), and developing online trust (0.07). The inconsistency coefficient is 0.06239 , less than 0.1 , which demonstrates a high reliability of the responses. 
Similarly, the resulting priority vectors of the alternatives concerning the social media networks are in order (see Tab. 4): developing online trust (0.77), providing online service quality (0.13), and ensuring online effective communication experience (0.08). The node comparisons with respect to social media networks generated by the software displays the inconsistency coefficient of 0.05156 , which is well below 0.1 , therefore, answers proving to be reliable.

Tab. 3 - Pairwise comparison decision matrix for a hotel website. Source: Authors' own research

\begin{tabular}{|l|l|l|l|l|}
\hline Hotel website & $\begin{array}{l}\text { Develop- } \\
\text { ing online } \\
\text { trust }\end{array}$ & $\begin{array}{l}\text { Providing } \\
\text { online serv- } \\
\text { ice quality }\end{array}$ & $\begin{array}{l}\text { Ensuring online } \\
\text { effective communica- } \\
\text { tion experience }\end{array}$ & $\begin{array}{l}\text { Priority } \\
\text { vectors }\end{array}$ \\
\hline Developing online trust & 1 & $1 / 7$ & $1 / 5$ & 0.07193 \\
\hline $\begin{array}{l}\text { Providing online service } \\
\text { quality }\end{array}$ & 7 & 1 & 3 & 0.64912 \\
\hline $\begin{array}{l}\text { Ensuring online effective } \\
\text { communication experience }\end{array}$ & 5 & $1 / 3$ & 1 & 0.27895 \\
\hline Sum of priority vectors & \multicolumn{5}{l}{} & 1 \\
\hline Inconsistency & & & 0.06239 \\
\hline
\end{tabular}

Tab. 4 - Priority vectors for the alternatives. Source: Authors' own research

\begin{tabular}{|l|l|l|l|l|}
\hline Alternatives & $\begin{array}{l}\text { Priority vectors } \\
\text { with respect to } \\
\text { a hotel website }\end{array}$ & $\begin{array}{l}\text { Priority vectors } \\
\text { with respect to } \\
\text { social media } \\
\text { networks }\end{array}$ & $\begin{array}{l}\text { Priority vectors } \\
\text { with respect to } \\
\text { online distribu- } \\
\text { tion channels }\end{array}$ & $\begin{array}{l}\text { Priority vectors } \\
\text { with respect to } \\
\text { review websites }\end{array}$ \\
\hline $\begin{array}{l}\text { Providing online } \\
\text { service quality }\end{array}$ & 0.64912 & 0.13916 & 0.57361 & 0.55907 \\
\hline $\begin{array}{l}\text { Ensuring online } \\
\text { effective commu- } \\
\text { nication experi- } \\
\text { ence }\end{array}$ & 0.27895 & 0.08767 & 0.36135 & 0.35219 \\
\hline $\begin{array}{l}\text { Developing on- } \\
\text { line trust }\end{array}$ & 0.07193 & 0.77317 & 0.06504 & 0.08875 \\
\hline $\begin{array}{l}\text { Sum of priority } \\
\text { vectors }\end{array}$ & 1 & 1 & 1 & 1 \\
\hline Inconsistency & 0.06239 & 0.05156 & 0.05156 & 0.05156 \\
\hline
\end{tabular}

The ranking in importance attributed by Respondent 1 to the alternatives with respect to online distribution channels is: providing online service quality $(0.57)$, ensuring online effective communication experience (0.36), and developing online trust (0.06). The quality of the matrix is illustrated by the inconsistency coefficient of 0.05156 , which proves again reliability of the responses. Finally, the ranking in importance attributed by Respondent 1 to the alternatives with 
respect to review websites is: providing online service quality (0.55), ensuring online effective communication experience (0.35), and developing online trust (0.08). The most preferred alternative in this case is the online service quality. Reliability of the responses is ensured again by the inconsistency coefficient of 0.05156 .

The overall synthesized priorities for all alternatives are shown in Tab. 5. Thus, the analysis for Respondent 1 leads us to the conclusion that the most appropriate strategy for creating social value in the hotel online environment is providing high quality of the online service (0.55), followed by ensuring effective online communication experience (0.33), and developing online trust (0.10). Moreover, the analysis concluded with a non-statistical aggregation of the five respondents' answers (Tab. 6 and Tab. 7). Priority vectors for the alternatives for all the other remaining respondents' answers are shown in Appendix 2.

Tab. 5 - Synthesized priorities for the alternatives. Source: Authors' own research

\begin{tabular}{|l|l|l|l|}
\hline & Ideals & Normals & Raw \\
\hline Developing online trust & 0.198134 & 0.109726 & 0.054863 \\
\hline Providing online service quality & 1.00000 & 0.553800 & 0.276900 \\
\hline $\begin{array}{l}\text { Ensuring online effective communication } \\
\text { experience }\end{array}$ & 0.607574 & 0.336474 & 0.168237 \\
\hline
\end{tabular}

Tab. 6 - Priority vectors for the aggregated responses with respect to the criteria. Source: Authors' own research

\begin{tabular}{|l|l|}
\hline Criteria & Priority vectors \\
\hline Hotel Website & 0.257033 \\
\hline Online Distribution Channels & 0.194121 \\
\hline Review Websites & 0.174042 \\
\hline Social Media Networks & 0.076865 \\
\hline
\end{tabular}

Tab. 7 - Overall synthesized priority vectors for the aggregated responses with respect to the alternatives. Source: Authors' own research

\begin{tabular}{|l|l|}
\hline Alternatives & Priority vectors \\
\hline $\begin{array}{l}\text { Ensuring online effective communication } \\
\text { experience }\end{array}$ & 0.303449 \\
\hline Developing online trust & 0.231480 \\
\hline Providing online service quality & 0.202433 \\
\hline
\end{tabular}

The aggregation was done using the geometric mean. As previously pinpointed, the representativeness rendered by the model is not a statistical representativeness, and it is given by the nature of the business and the role that the key actor from whom we collected responses plays in the hotel online environment. The aggregation based on the geometric mean is specific to group decisions. A large number of respondents would retrieve a non-significant result, and the answers of the respondents might cancel each other. 
Consequently, the analysis for the aggregated responses led us to the following conclusions. The most suitable strategy for creating social value in the hotel online environment is ensuring an effective online communication experience with an aggregated priority vector of 0.30 , followed by developing online trust 0.23 , and, finally, providing online service quality with an aggregated priority vector of 0.20 . The most important criterion in choosing the social value in the hotel online environment is the hotel website with an aggregated priority vector of 0.25 , followed by the online distribution channels (0.19), review websites (0.17), and surprisingly, social media (0.07) ended up as last. These results are consistent with Rong et al.'s (2009) findings who demonstrated that the website quality has widely been recognized as a critical step to drive the business online. Other researches (e.g., Bai et al. 2008) have also shown that the website quality has a direct and positive impact on the level of customer satisfaction, and that the customer satisfaction level influences directly and positively the purchase intentions.

According to our research results, out of the three alternatives --online trust, online service quality and online communication experience-- online effective communication's priority vector was remarkably higher that the rest. The finding is not surprising, as website owners, managers and marketing experts are devoted to ensure a two-way communication and to enhance customer engagement around their product, service or website in general. The results might also suggest that in order to reach the point where the online service quality is perceived by an individual user as important, websites need to make a positive impact on the individual user's level and form of communication. However, social media platforms became unquestionably an important way to communicate and engage customers and can be used as a valuable way to find immediate feedback from customers, whether a product or a service has potential or not (Leung et al., 2015). Therefore, hotels can apply for a handful of social media strategies depending on the customers they want to engage.

\section{CONCLUSION}

The study proposed a research model that analyses the possibilities the hoteliers have to create and maximize the social value of their online environment to increase sales and hotel's performance. It also discussed the opportunities the hotel managers can take to improve their hotel online decision-making strategy to convert more effectively visitors into actual customers. The literature reviewed and field research conducted outlined a perimeter consisting of four key dimensions of the hotel online environment, namely: hotel websites, social media platforms, online distribution channels, and review websites. Also, the research model developed in the paper pinpointed three possibilities of creating social value in the hotel online environment: building online trust, ensuring high quality of the online service, and providing effective online communication experience. The analytic hierarchy process method employed in the paper proved that the most suitable strategy for creating social value in the hotel online environment for our sample companies was ensuring effective online communication experience, and the most important criterion in choosing the online social value was the hotel website. Thus, in order to reach the point where the hotel online service is perceived by an individual user as useful and valuable, websites need to make a positive impact on the individual visitor's level of understanding and form of communication (Kim et al., 2017), which might be vital in making the decision to become a purchaser or remain a browser (Rong et al., 2009; Alshibly, 2015). 
The analytic hierarchy process appeared to be a promising support tool for shared decision making between travellers and hoteliers, for evaluation of dimensions of the hotel online environment, and evaluation and selection of strategies for online social value creation and maximization. We expect that the analytic hierarchy process research will continue to be an important component of hotel and tourism industry research, as well as other sectors of activity (Liberatore \& Nydick, 2008; Hasan \& Rahman, 2017).

The in-depth analysis of the four dimensions of the hotel online environment and the questionnaire-based survey conducted among selected industry experts in Romania and Hungary have given interesting ideas about potential areas of the hotel online environment where online social value may be obtained. We assumed that social media networks and review websites offer a possibility for the hotels to create social value. This, however, was only partly proven by the research, respondents from the industry clearly preferring hotel websites a lot more compared to review websites and social media platforms that ended up behind all other criteria, although it is not conclusive, and requires further research.

The paper findings raise also new questions in respect to how trust, communication and service quality are affecting the online environment of the hotel and in what regards these factors are helping with developing the online social value. Also, further research will show how a given sample of hotels will prove or disapprove the existence of a clearly outlined online environment in practice and how the online social value can relate to this environment.

Like other researches, the current study is not without limitations. The main limitations of our research could relate to the number of questionnaires interpreted in the study and the specificity of the hotel online environment from which the respondents have been selected, which might differ by country or region. Also, the data collected might not incorporate all the key players that are active in the area or might not reflect all their perspectives. Even so, our findings proved to meet the reliability tests as the statistical representativeness was not required.

The study offers useful insights for hoteliers on how they can realistically analyse the potential to enhance the social value of their hotel online platforms and improve the business. However, hoteliers need to ensure that they are using appropriate strategies in different types of both online and offline channels. The paper facilitates the path of hoteliers to proactively incorporate strategies for maximizing social value online into their efforts to remain competitive in the industry and improve their business.

Our research can be extended along several directions. First, a future research should explore more precisely what customers do value when choosing a hotel and staying at a hotel and with what intensity they value these elements. This will help hoteliers understand better what type of social value they should focus their efforts on in the online environment. Such a research might test for example the degree to which availability of relevant and reliable information on the hotel website will enhance the online trust and reduce risk and uncertainty of using online channels for booking a hotel. Also, another stream of research should evaluate the intensity with which the size and volume of information shared on the hotel website, its usability and possibilities of making comparisons will contribute to increasing the online service quality of the hotel. 


\section{References}

1. Agapie, A. (2014). Consistency in the context of AHP: half friend, balf foe'. Pittsburgh: Creative Decision Foundation on behalf of the International Symposium on the Analytic Hierarchy Process.

2. Akehust, G. (2009). User generated content: the use of blogs for tourism organizations and tourism consumers. Service Business, 3 (1), 51-61. http://dx.doi.org/10.1007/s11628-0080054-2.

3. Alshibly, H. H. (2015). Customer perceived value in social commerce: An exploration of its antecedents and consequences. Journal of Management Research, 7 (1), 17-37. http://dx.doi. org/10.5296/jmr.v7i1.6800.

4. Aykan, A., \& Dagdeviren, M. (2014). A hybrid multi-criteria decision making model to evaluate hotel websites. International Journal of Hospitality Management, 36, 263-271. http:// dx.doi.org/10.1016/j.ijhm.2013.10.002.

5. Bai, B., Law, R., \& Wen, I. (2008). The impact of website quality on customer satisfaction and purchase intentions: Evidence from Chinese online visitors. International Journal of Hospitality Management, 27 (3), 391-402. http://dx.doi.org/10.1016/j.ijhm.2007.10.008.

6. Browning, V., So, K., \& Sparks, B. A. (2013). The influence of online reviews on consumers' attributions of service quality and control for service standards in hotels'. Journal of Travel \& Tourism Marketing, 30 (1-2), 23-40. http://dx.doi.org/10.1080/10548408. 2013.750971.

7. Carroll, B., \& Siguaw, J. (2003). The evolution of electronic distribution: Effects on hotels and intermediary. Cornell Hotel and Restaurant Administration Quarterly, 44 (4), 38-50.

8. Chiang, C. F., \& Shawn Jang, S. C. (2007). The effects of perceived price and brand image on value and purchase intention: leisure travellers' attitudes toward online hotel booking. Journal of Hospitality \& Leisure Marketing, 15 (3), 49-69.

9. Corritore, C. L, Marble, R. P., Wiedenbeck, S., Kracher, B., \& Chandran, A. (2005). Measuring online trust of websites: Credibility, perceived ease of use, and risk. Omaha: AMCIS 2005 Proceedings.

10. Daun, W., \& Klinger, R. (2006). Delivering the message: How premium hotel brands struggle to communicate their value proposition. International Journal of Contemporary Hospitality Management, 18 (3), 246-252. http://dx.doi.org/10.1108/09596110610658643.

11. Elliott, K. M., \& Meng, J. (2011). Hotel website information: How satisfied are customers with what hotels provide? International Journal of Business Strategy, 11 (1), 120-129. Retrieved from http://www.freepatentsonline.com/article/International-Journal-BusinessStrategy/272484862.html.

12. Freedman, S., \& Jin, G. Z. (2017). The information value of online social networks: Lessons from peer-to-peer lending. International Journal of Industrial Organization, 51, 185-222. http://dx.doi.org/10.1016/j.ijindorg.2016.09.002.

13. Goh, J. M., Gao, G. G., \& Agarwal, R. (2016). The creation of social value: Can an online health community reduce rural-urban health disparities? MIS Quarterly: Management Information Systems, 40 (1), 247-263. 
14. Hadad, S. (2015). Analytic hierarchy process analysis for choosing a corporate social entrepreneurship strategy. Management \& Marketing. Challenges for the Knowledge Society, 10 (3), 185-207. http://dx.doi.org/10.1515/mmcks-2015-0014.

15. Hasan, N., \& Rahman, A. A. (2017). Ranking the factors that impact customers' online participation in value co-creation in service sector using analytic hierarchy process. International Journal of Information Systems in the service sector, 9 (1), 37-53. http://dx.doi. org/10.4018/IJISSS.2017010103.

16. Ho, W., Dey, P. K., \& Lockstrom, M. (2011). Strategic sourcing: A combined QFD and AHP approach in manufacturing. Supply Chain Management. An International Journal, 16 (6), 446-461. http://dx.doi.org/10.1108/13598541111171093.

17. Hsieh, Y. J. (2012). Hotel companies' environmental policies and practices: a content analysis of their web pages. International Journal of Contemporary Hospitality Management, 24 (1), 97-121. http://dx.doi.org/10.1108/095961112.

18. Hu, T., Kettinger, W.J., Poston, R. S. (2015). The effect of online social value on satisfaction and continued use of social media. European Journal of Information Systems, 24 (4), 391-410. http://dx.doi.org/10.1057/ejis.2014.22.

19. Ip, C., Law, R., \& Lee, H. A. (2012). The evaluation of hotel website functionality by fuzzy analytic hierarchy process. Journal of Travel « Tourism Marketing, 29 (3), 263-278, http:// dx.doi.org/10.1080/10548408.2012.666173.

20. Jarvenpaa, S. L., \& Leidner, D. E. (1998). Communication and trust in global virtual teams. Journal of Computer-Mediated Communication, 3 (4). http://dx.doi.org/10.1111/j.1083-6101.1998. tb00080.x.

21. Kim, S. Y., Kim, J. U., \& Park, S. C. (2017). The effects of perceived value, website trust and hotel trust on online hotel booking intention. Sustainability, 9 (12), 1-14. http://dx.doi. org/10.3390/su9122262.

22. Law, R. (2009). Disintermediation of hotel reservations: The perception of different groups of online buyers in Hong Kong. International Journal of Contemporary Hospitality Management, 21 (6), 766-772. http://dx.doi.org/10.1108/09596110910976007.

23. Law, R., \& Jogaratnam, G. (2005). A study of hotel information technology applications. International Journal of Contemporary Hospitality Management, 17 (2), 170-180. http://dx.doi. org/10.1108/09596110510582369.

24. Law, R., \& Hsul, C. H. C. (2006). Importance of hotel website dimensions and attributes: Perceptions of online browsers and online purchasers. Journal of Hospitality \& Tourism Research, 30 (3), 295-312. http://dx.doi.org/10.1177/1096348006287161.

25. Law, R., Ho, D., \& Cheung, C. (2004). A study of the functionality of hotel websites in mainland China and the United States. Journal of the Academy of Business and Economics, 3 (1), 202-209. http://dx.doi.org/10.1016/j.ijhm.2005.03.001.

26. Leung, Xi, Bai B., \& Stahura, K. A. (2015). The marketing effectiveness of social media in the hotel industry: A comparison of Facebook and Twitter. Journal of Hospitality \& Tourism Research, 39, 147-169. http://dx.doi.org/10.1177/1096348012471381. 
27. Liang, L., Wang, G., Hua, Z., \& Zhang, B. (2008). Mapping verbal responses to numerical scales in the analytic hierarchy process. Socio-Economic Planning Sciences, 42, 46-55. http:// dx.doi.org/10.1016/j.seps.2005.10.006.

28. Liberatore, M. J., \& Nydick, R. L. (2008). The analytic hierarchy process in medical and health care decision making: A literature review. European Journal of Operational Research, 189 (1), 194-207. http://dx.doi.org/10.1016/j.ejor.2007.05.001.

29. McIntyre, S. H., McQuarrie, E. F., Shanmugam, R. (2016). How online reviews create social network value: the role of feedback versus individual motivation. Journal of Strategic Marketing, 24 (3-4), 295-310. http://dx.doi.org/10.1080/0965254X.2015.1095218.

30. Ordoobadi, S. M. (2010). Application of AHP and Taguchi loss functions in supply chain. Industrial Management Data Systems, 110 (8-9), 1251-1269. http://dx.doi.org/10.1108/0263557 1011077861.

31. Padilla-Melendez, A, \& Rosa del Aguila-Obra, A. (2013). Web and social media usage by museums: Online value creation. International Journal of Information Management, 33 (5), 892-898. http://dx.doi.org/10.1016/j.ijinfomgt.2013.07.004.

32. Prahalad, C. K., \& Ramaswamy, V. (2004). Co-creation experiences: The next practice in value creation. Journal of Interactive Marketing, 18 (3), 5-14. http://dx.doi.org/10.1002/ dir.20015.

33. Pranić, L., Garbin Praničević, D., \& Arnerić, J. (2014). Hotel website performance: evidence from a transition country. Tourism and Hospitality Management, 20 (1), 45-60. Retrieved from http://hrcak.srce.hr/123777?lang=en.

34. Reichenberger, I. (2017). C2C value co-creation through social interactions in tourism. International Journal of Tourism Research, 19 (6), 629-638. http://dx.doi.org/10.1002/jtr.2135.

35. Rong, J., Li, G., \& Law, R. (2009). A contrast analysis of online hotel web service purchasers and browsers. International Journal of Hospitality Management, 28 (3), 466-478. DOI: 10.1016/j.ijhm.2009.02.002.

36. Saaty, R. W. (1987). The analytic hierarchy process-what it is and how it is used. Mathematical Modelling, 9 (3-5), 161-163. http://dx.doi.org/10.1016/0270.

37. Saaty, T. L. (2008). Decision making with the analytic hierarchy process. International Journal of Services Sciences, 1 (1), 83-98. Retrieved from http://citeseerx.ist.psu.edu/viewdoc/downloa d?doi=10.1.1.409.3124\&rep=rep1\&type $=$ pdf.

38. Saaty, T. L., \& Vargas, L. G. (2012). Models, methods, concepts and applications of the Analytic Hierarchy Process. Berlin: Springer.

39. Schmidt, S., Cantallops, A. S., \& Santos, C. P. (2008). The characteristics of hotel websites and their implications for website effectiveness. Tourism Management, 28 (2), 504-516. http:// dx.doi.org/10.1016/j.ijhm.2007.08.002.

40. Shankar, V., Urban Glen, L., \& Sultan, F. (2002). Online trust: a stakeholder perspective, concepts, implications, and future directions. Journal of Strategic Information Systems, 11, 325-344. Retrieved from http://citeseerx.ist.psu.edu/viewdoc/download; jsessionid=C2A9 6ADF0E659515DA27F821863DAF06?doi=10.1.1.470.7799\&rep=rep1\&type=pdf. 
41. Shankar, V., Smith, A. K., \& Rangaswamy, A. (2003). Customer satisfaction and loyalty in online and offline environments. International Journal of Research in Marketing, 20 (2), 153-175. http://dx.doi.org/10.1016/S0167-8116(03)00016-8.

42. Sparks, B. A., Perkins, H., \& Buckley, R. (2013). Online travel reviews as persuasive communication: The effects of content type, source, and certification logos on consumer behaviour. Tourism Management, 39, 1-9. http://dx.doi.org/10.1016/j.tourman.2013.03.007.

43. Sparks, B., \& Browning, V. (2011). The impact of online reviews on hotel booking intentions and perception of trust. Tourism Management, 32 (6), 1310-1323. http://dx.doi. org/10.1016/j.tourman.2010.12.011.

44. Tanău, A.D., \& Khorshidi, M. (2016). New business models for state companies in the oil industry. Management \& Marketing. Challenges for the Knowledge Society, 11 (3), 484-497. http:// dx.doi.org/10.1515/mmcks-2016-0011.

45. Wu, H. J. C., \& Liang, R. D. (2009). Effect of experiential value on customer satisfaction with service encounters in luxury-hotel restaurants. International Journal of Hospitality Management, 28 (4), 586-593. http://dx.doi.org/10.1016/j.ijhm.2009.03.008 .

46. Xie, K. L., Zhang, Z. [Zili], \& Zhang, Z. [Ziqiong] (2014). The business value of online consumer reviews and management response to hotel performance. International Journal of Hospitality Management, 43, 1-12. . http://dx.doi.org/ 10.1016/j.ijhm.2014.07.007.

47. Ye, Q., Law, R., Gu, B., \& Chen, W. (2011). The influence of user-generated content on traveller behaviour: An empirical investigation on the effects of e-word-of-mouth to hotel online bookings. Computers in Human Behaviour, 27 (2), 634-639. http://dx.doi.org/10.1016/ j.chb.2010.04.014.

48. Ye, Q., Li, H., Wang, Z., \& Law, R. (2014). The influence of hotel price on perceived service quality and value in e-tourism. An empirical investigation based on online traveller reviews. Journal of Hospitality \& Tourism, 38 (1), 23-39. http://dx.doi.org/10.1177/1096348012442540.

\section{Contact information}

Prof. Carmen Păunescu, Ph.D.

Bucharest University of Economic Studies

Faculty of Business Administration in Foreign Languages

UNESCO Department for Business Administration

Calea Griviei 2-2A, Bucharest - 010731, District 1

Romania

E-mail: carmen.paunescu@ase.ro

Remus Moraru, Ph.D. student

Bucharest University of Economic Studies

Doctoral School for Business Administration

Calea Griviei 2-2A, Bucharest - 010731, District 1

Romania

E-mail:moraru_remus@yahoo.com 


\section{Appendix 1}

Tab. 1 - Priority vectors for the criteria

\begin{tabular}{|l|l|l|l|l|l|}
\hline \multirow{2}{*}{ Criteria } & \multicolumn{5}{|l}{ Priority vectors } \\
\cline { 2 - 6 } & $\begin{array}{l}\text { Respondent } \\
1\end{array}$ & $\begin{array}{l}\text { Respondent } \\
2\end{array}$ & $\begin{array}{l}\text { Respondent } \\
3\end{array}$ & $\begin{array}{l}\text { Respondent } \\
4\end{array}$ & $\begin{array}{l}\text { Respondent } \\
5\end{array}$ \\
\hline Review Websites & 0.43404 & 0.16415 & 0.07444 & 0.21660 & 0.14266 \\
\hline $\begin{array}{l}\text { Online Distribu- } \\
\text { tion Channels }\end{array}$ & 0.42291 & 0.68967 & 0.21238 & 0.48490 & 0.08145 \\
\hline Hotel Website & 0.09539 & 0.09648 & 0.66553 & 0.25678 & 0.71331 \\
\hline $\begin{array}{l}\text { Social Media } \\
\text { Networks }\end{array}$ & 0.04765 & 0.04970 & 0.04764 & 0.04172 & 0.06258 \\
\hline $\begin{array}{l}\text { Sum of priority } \\
\text { vectors }\end{array}$ & 1 & 1 & 1 & 1 & 1 \\
\hline Inconsistency & 0.10533 & 0.10851 & 0.03276 & 0.10126 & 0.08062 \\
\hline
\end{tabular}

\section{Appendix 2}

Tab. 1 - Priority vectors for the alternatives for Respondent 2

\begin{tabular}{|l|l|l|l|l|}
\hline \multirow{2}{*}{ Alternatives } & \multicolumn{4}{|l|}{ Priority vectors with respect to } \\
\cline { 2 - 5 } & $\begin{array}{l}\text { a hotel } \\
\text { website }\end{array}$ & $\begin{array}{l}\text { social media } \\
\text { networks }\end{array}$ & $\begin{array}{l}\text { online distribu- } \\
\text { tion channels }\end{array}$ & $\begin{array}{l}\text { review } \\
\text { websites }\end{array}$ \\
\hline Providing online service quality & 0.08808 & 0.45455 & 0.13111 & 0.20813 \\
\hline $\begin{array}{l}\text { Ensuring online effective com- } \\
\text { munication experience }\end{array}$ & 0.71723 & 0.09090 & 0.20813 & 0.13111 \\
\hline Developing online trust & 0.19469 & 0.45455 & 0.66076 & 0.66076 \\
\hline Sum of priority vectors & 1 & 1 & 1 & 1 \\
\hline Inconsistency & 0.09040 & 0.00000 & 0.05156 & 0.05156 \\
\hline
\end{tabular}

Tab. 2 - Priority vectors for the alternatives for Respondent 3

\begin{tabular}{|l|l|l|l|l|}
\hline \multirow{2}{*}{ Alternatives } & \multicolumn{4}{|l|}{ Priority vectors with respect to } \\
\cline { 2 - 5 } & $\begin{array}{l}\text { a hotel } \\
\text { website }\end{array}$ & $\begin{array}{l}\text { social media } \\
\text { networks }\end{array}$ & $\begin{array}{l}\text { online distribu- } \\
\text { tion channels }\end{array}$ & $\begin{array}{l}\text { review } \\
\text { websites }\end{array}$ \\
\hline $\begin{array}{l}\text { Providing online service } \\
\text { quality }\end{array}$ & 0.12532 & 0.13916 & 0.45793 & 0.09554 \\
\hline $\begin{array}{l}\text { Ensuring online effective } \\
\text { communication experience }\end{array}$ & 0.07895 & 0.08767 & 0.12601 & 0.76038 \\
\hline Developing online trust & 0.79573 & 0.77317 & 0.41606 & 0.14408 \\
\hline Sum of priority vectors & 1 & 1 & 1 & 1 \\
\hline Inconsistency & 0.05156 & 0.05156 & 0.00885 & 0.07721 \\
\hline
\end{tabular}


Tab. 3 - Priority vectors for the alternatives for Respondent 4

\begin{tabular}{|l|l|l|l|l|}
\hline \multirow{2}{*}{ Alternatives } & \multicolumn{4}{|l|}{ Priority vectors with respect to } \\
\cline { 2 - 5 } & $\begin{array}{l}\text { a hotel } \\
\text { website }\end{array}$ & $\begin{array}{l}\text { social media } \\
\text { networks }\end{array}$ & $\begin{array}{l}\text { online } \\
\text { distribution } \\
\text { channels }\end{array}$ & $\begin{array}{l}\text { review } \\
\text { websites }\end{array}$ \\
\hline $\begin{array}{l}\text { Ensuring online effective communica- } \\
\text { tion experience }\end{array}$ & 0.17003 & 0.81421 & 0.32748 & 0.20670 \\
\hline Developing online trust & 0.70736 & 0.11398 & 0.41260 & 0.73519 \\
\hline Sum of priority vectors & 1 & 1 & 1 & 1 \\
\hline Inconsistency & 0.10370 & 0.05156 & 0.05156 & 0.10260 \\
\hline
\end{tabular}

Tab. 4 - Priority vectors for the alternatives for Respondent 5

\begin{tabular}{|l|l|l|l|l|}
\hline \multirow{2}{*}{ Alternatives } & \multicolumn{2}{|l|}{ Priority vectors with respect to } \\
\cline { 2 - 5 } & $\begin{array}{l}\text { a hotel } \\
\text { website }\end{array}$ & $\begin{array}{l}\text { social media } \\
\text { networks }\end{array}$ & $\begin{array}{l}\text { online } \\
\text { distribution } \\
\text { channels }\end{array}$ & $\begin{array}{l}\text { review } \\
\text { websites }\end{array}$ \\
\hline $\begin{array}{l}\text { Ensuring online effective communi- } \\
\text { cation experience }\end{array}$ & 0.81421 & 0.80821 & 0.81421 & 0.80821 \\
\hline Developing online trust & 0.07180 & 0.06227 & 0.07180 & 0.06227 \\
\hline Sum of priority vectors & 1 & 1 & 1 & 1 \\
\hline Inconsistency & 0.05156 & 0.10040 & 0.05156 & 0.10040 \\
\hline
\end{tabular}

